\title{
THE LEGAL CLAMOUR OVER CANADIAN OFF-SHORE MINERALS
}

\author{
IVAN L. HEAD*
}

\begin{abstract}
"There is no silence upon the earth ... like the silence under the sea." -E. J. Pratt
\end{abstract}

The wealth lying silently beneath the sea has attracted the interest of men for centuries. Until relatively recently this interest has been more imaginative than practical, but now giant off-shore drilling rigs are able to exploit from the surface many of the submarine resources heretofore thought to be accessible only to the likes of Captain Nemo. Hand in hand with the development of this ability to find and win underwater resources has come the need for rules to accommodate and regulate exploration and drilling activities. A need which has been recognized and met. The success of the international community in formulating such rules is a heartening example of its vitality and of the high regard which its members hold for the role of law in the conduct of their affairs. The Convention on the Continental Shelf ${ }^{1}$ is an excellent illustration of "the progressive development of international law.""

National claims to the ocean floor have been advanced in different places for different purposes for many years. These have been couched in terms of exclusive jurisdiction of the superjacent waters, ${ }^{3}$ of the right to work the mines and minerals, ${ }^{4}$ and of ownership of parts of the seabed itself. $^{5}$ At least one individual has made a claim. The records of the United States State Department reveal that in 1944 a gentleman by the name of A. Byron Hunicke claimed that he had developed a means "for making the sea floor accessible to human exploitation" and that he claimed "full title and dominion in submerged lands and the waters above them lying seaward of the off-shore limit of territorial waters of nations abutting the sea."

To States employing a unitary form of government, the declaration in the Continental Shelf Convention that "The coastal State exercises over the continental shelf sovereign rights for the purpose of exploring it and exploiting its natural resources" offered no constitutional problem. To federal States such as Canada, Australia, or the United States of America, however, there arose immediately the question of which of the two levels of government, federal or provincial (state), was entitled to enjoy the benefits of the Article. In Australia a somewhat complicated \footnotetext{
- B.A., LL.B. (Alta.), LL.M. (Harvard), Associate Professor of Law, University of External Affairs, Canada, who has undertaken from time to time certain legal studies for the Department. The views expressed herein are, of course, entirely his own.

1 U.N. Doc. A/CONF. 13/L.55.

2 United Nations Charter. Article 13 (1) (a)

Regulation No. 3 of 1811 for the Protection of His Majesty's Pearl Banks of Ceylon: Ceylon Legislative Enactments, Vol. 1 (1707-1888), at 51

4 Cornwall Submarine Mines Act. (1858) 21 \& 22 Vict., c. 109.

See, e.g., the judgment of Lord Kyllachy in Lord Advocate v. Clyde Navigation Trustees, (1891) 19 Rettie 174.

o Whiteman, Digest of International Law, Vol. 4, at 740

i Article 2 (1).
} 
scheme has evolved which by-passes the constitutional separation of authority and which provides for joint Commonwealth-state arrangements over the off-shore resources both within and beyond territorial limits. Briefly, administration of off-shore activities is in the hands of the states but subject to Commonwealth supervision; royalties are shared equally between the Commonwealth and the adjacent state. ${ }^{8}$ In the United States a contest occurred between several of the coastal states and the United States with respect to ownership of the seabed beneath the territorial sea; ${ }^{0}$ following litigation a legislative enactment of the United States Congress transferred to the coastal states the bed of the sea seaward to the territorial limits. ${ }^{10}$

In Canada the question of federal or provincial paramountcy has never been determined, although it did arise from time to time prior to 1965 . In 1913 the Judicial Committee of the Privy Council reviewed a judgment of the Supreme Court of Canada concerning British Columbia fisheries. ${ }^{11}$ B.C. had claimed jurisdiction to certain fishing areas, one of which formed a belt 3 miles wide seaward into the Pacific. The province argued that it had a proprietary title to the seabed. Viscount Haldane replied that the Board felt "relieved from expressing any opinion on the question whether the provincial Crown has a right of property in the bed of the sea below low water mark, to what is known as the three-mile limit"12 because the question about fisheries could be decided independently of the status of the sea bed. In 1921 another fisheries case came before the Privy Council, this time involving a claim by Quebec. ${ }^{13}$ The Court refused to say whether Quebec had any property rights in territorial waters on the ground that more was involved than an agreement between a province and the federal government of a single country, that this was "really a question of public international law."14

Much more recently the Supreme Court of Nova Scotia faced a problem involving the right of a county to assess for taxation purposes property in submarine mines. ${ }^{15}$ An objection had been taken to the tax assessment on the grounds that the mining property was not within the county. The Court proceeded cautiously, as reflected in the judgment of MacDonald, J. that it "should refuse to be drawn unnecessarily into a pronouncement of such a nature as the proprietary interest in the maritime belt."10

Inexorably, however, the question remained alive. With the development and perfection of deep water drilling techniques, oil companies sought permission to explore for petroleum off Canada's coasts. Canada issued permits for these activities. The adjacent provinces soon de-

8 See R. D. Lumb, "The Law of the Sea and Australian Off-shore Areas" (San Lucia, University of Queensland Press, 1966). Each of the Australian states has enacted legislation claiming jurisdiction to the minerals off its own shores: Petroleum Act Amendment Act, No. 66 of 1954 (W.A.): Mining (Amendment) Act, No 57 of 1963 (N.S.W.): Underseas Mineral Resources Act, No. 7095 of 1963 (Vict.): Mineral Resources (Adjacent Submarine Areas) Act, No. 26 of 1964 (Qld.): Mining (Petroleum) Amendment Act. No. 42 of 1963 (S.A.); Mining Act. No. 17 of 1962 (Tas.).

O U.S. v. California, 332 U.S. 19. U.S. v. Texas, 339 U.S. 707. U.S. v. Louisiana, 339 U.S. 699 .

10 The Submerged Lands Act (1953), 67 Stat. 29; The Outer Continental Shelf Lands Act (1953), 67 Stat. 462 declares United States jurisdiction over the sea bed and subsoil in the seaward areas.

11 Att. Gen. for B.C. v. Att. Gen. for Canada, [1914] A.C. 153.

12 Id., at 174.

13 Att. Gen. for Canada v. Att. Gen. for Quebec, [1921] 1 A.C. 413.

14 Id., at 431 .

10 Id., at 632 . 
manded that the companies seek provincial permission, on the basis that these areas were within provincial jurisdiction. Faced with this contest, companies protected their position by taking out both federal and provincial permits, sometimes for the same area. Inevitably, complications arose as the two levels of government issued permits to the same areas but to different companies.

It should not be assumed that these provincial claims are modest in extent. British Columbia claims an area of seabed approximately equal in extent to $50 \%$ of the present provincial area of 366,255 square miles. A provincial cabinet minister has been quoted as saying that B.C. intends to go seaward "as far as you can go". The Deputy Attorney-General has talked in terms of "colonization" of the ocean floor. The silence under the sea is not matched by silence on shore.

Eight of Canada's ten provinces have seacoasts. ${ }^{17}$ The governments of several of these provinces expressed the wish that the conflicting federal-provincial claims be dealt with by negotiation in a conference called for that purpose. The federal government, on the other hand, demurred, saying that negotiations could not properly proceed until the legal position of the parties had been made clear. And so by an Order-in-Council dated April 26th, 1965, the Canadian Government referred the contest to the Supreme Court of Canada. ${ }^{18}$ The Court was asked to consider five questions, three pertaining to the seabed beneath territorial waters and two to the seabed seaward therefrom to the limit of the continental shelf. The questions were framed so as to deal only with the waters off the coast of British Columbia. ${ }^{19}$

The Reference is now before the Supreme Court.

II

The questions facing the Court arise out of an internal, constitutional contest: which of Canada or British Columbia has the superior claim to the offshore, submarine resources. Constitutional though the question in essence is, it is not exclusively one of municipal law. The Court will be required to consider the nature and extent of a number of principles

17 Only Alberta and Saskatchewan do not: Manitoba's coast fronts on Hudson Bay.

18 Order-in-Council P.C. 1965-750. The Reference was made pursuant to The Supreme Court Act, 1952 R.S.C., c. 259, s. 55.

19 The Order-in-Council reads, in its active part, as follows:

1.. His Execellency the Governor-General-in-Council, under and by virtue of the authority conferred by section 55 of the Supreme Court Act, is pleased to refer and doth hereby refer the following questions to the Supreme Court of Canada for consideration:

1. In respect of the lands, including the mineral and other natural resources, of the sea bed and subsoil seaward from the ordinary low-water mark on the coast of the mainland and the several islands of British Columbia, outside the harbours, bays, estuaries and other similar inland waters, to the outer limit of the territorial sea of Canada, as defined in the Territorial Sea and Fishing Zones Act, Statutes of Canada 1964, Chapter 22, as between Canada and British Columbia,

(a) Are the said lands the property of Canada or British Columbia?

(b) Has Canada or British Columbia the right to explore and exploit the said lands?

(c) Has Canada or British Columbia legislative jurisdiction in relation to the said lands?

2. In respect of the mineral and other natural resources of the sea bed and subsoil beyond that part of the territorial sea of Canada referred to in Question 1, to a depth of 200 metres or, - beyond that limit, to where the depth of the superjacent waters admits of the exploitation of the mineral and other natural resources of the said areas, as between Canada and British Columbia,

(a) Has Canada or British Columbia the right to explore and exploit the said mineral and other natural resources?

(b) Has Canada or British Columbia. legislative jurisdiction in relation to the said mineral and other natural resources?" 
of international law. In this article an attempt will be made to trace and discuss several of these.

The extent and the character of the sovereign rights exercisable by a nation-State, for example, are determined by international law. These rights may be described, or measured, in terms of jurisdiction (i.e. imperium) or of proprietary interests (i.e. dominium). But international law, seeking as it does to make regular the relations among States, (which, with certain international organizations, are the only members of the international community) is incapable of articulating how the exercise of those sovereign rights is to be distributed among a number of competing repositories within a single State. That division is the exclusive concern of the municipal (domestic) constitutional law of the State. It is an internal contest. That is why the Court's ultimate decision, following its consideration and analysis of pertinent principles of international law, will be one of Canadian constitutional interpretation.

That confusion may result from this kind of judicial examination is obvious. The Order-in-Council, in Question 1(a), asks "are the said lands the property of Canada or British Columbia?" The word "property" is a municipal law term; international law speaks of "territory". The two terms are not interchangeable for they anticipate disparate concepts. At common law, real property within the realm is not conceived as existing without being subject to some degree of tenure whether or not occupied. All lands within Her Majesty's domain are the object of socage, which is to say that the Queen is lord paramount of all land within the realm. (The concept of bona vacantia, for example, is not applicable to realty, only to personalty.)

$\ldots$ it is many years since there were any enforceable rights to preserve evidence of the relationship of lord and tenant, and consequently the land is presumed to be held directly of the Crown. Yet despite the sweeping changes made by statute, 'the fundamental principles of the law of ownership of land remain the same as before the legislation of 1925. Land is still the object of feudal tenure; the King remains the lord paramount of all the land within the realm; every parcel of land is still held of some lord ... and the greatest interest which any subject can have in land is still an estate in fee simple and no more.'20

International law, on the other hand, does not demand that all territory be subject at all times to the sovereignty of some State; it re- cognizes that territory may in addition be either res communis (subject to the use of all States, e.g. the high seas), or terra nullius (subject for the time being to the sovereignty of no State, e.g. undiscovered or unoccupied land, or land considered by international law to be incapable of attracting sovereignty).

At the basis of international law lies the notion that a state occupies a definite part of the surface of the earth, within which it normally exercises, subject to the limitations imposed by international law, jurisdiction over persons and things to the exclusion of the jurisdiction of other states. When a state exercises an authority of this kind over a certain territory it is popularly said to have 'sovereignty' over the territory, but that much-abused word is here used in a rather special sense. It refers here not to a relation of persons to persons, nor to the independence of the state itself, but to the nature of rights over territory; and in the absence of any better word it is a convenient way of contrasting the fullest rights over territory known to the law with the minor territorial rights to be later mentioned. Territorial sovereignty bears an obvious resemblance to ownership in private law, less marked, however, today than it was in the days of the patrimonial state, when a kingdom and everything in it was regarded as

20 R. E. Megarry, "A Manual of the Law of Real Property", (London, Stevens, 1947), at 25-6. 
being to the king very much what a landed estate was to its owner. As a result of this resemblance early international law borrowed the Roman rules for the acquisition of property and adapted them to the acquisition of territory, and these rules are still the foundation of the law on the subject.

The sovereignty of territory may be acquired by occupation, prescription, cession, conquest, and accretion. ${ }^{21}$

This distinction is vital to a consideration of the questions referred to the Court. British Columbia entered Confederation in 1871. The province's claim to the seabed of the territorial sea and to the continental shelf must either be rooted in a title predating that entry or must be the object of some subsequent acquisition. If, as Canada argues, international law in 1871 recognized no sovereign rights in the continental shelf, British Columbia's claim must rest on the alternate footing. It is not inconsistent with international legal principles that territory is not for a period capable of attracting sovereignty; unlike land at common law it is able to exist without an "owner".

\section{III}

Question 2 of the Reference concerns the resources of the seabed and subsoil beyond the territorial sea: to the point where the superjacent waters reach a depth of 200 metres, or beyond as far as they admit of exploitation. This question deals with that part of the ocean floor now called the continental shelf; the wording corresponds to that in Article 1 of the Continental Shelf Convention. ${ }^{22}$

In order properly to deal with Question 2 the Supreme Court must consider at what date international law accepted into its corpus the territorial and jurisdictional concept known as "the continental shelf."

The territorial extent of a nation-State is of consequence to all members of the international community. Accordingly, a body of international law concerning territory has been built up over the centuries and is now in all important aspects accepted by the great majority of States. These principles of international law reflect the changing concepts of territory and annexation which the international community has from time to time adopted as historic circumstance has made necessary. The periods of great discoveries, of European colonization, of intensive exploration, and of scientific achievements have all contributed to the shaping of these concepts just as the changing needs of the peoples of England and Canada have contributed to the evolution of the common law.

Should a State attempt to extend unilaterally its boundaries and claim to enlarge the territorial extent of its sovereignty, the legality of its acts would be assessed by reference to the applicable principles of international law. If the claim when made was of a sort not in accord with the then law, it would not be recognized by other States. Because international law is no more static than is the common law, claims and concepts acceptable in 1967 may not have been recognized a century

21 J. L. Brierly, "The Law of Nations", (Oxford, 6th ed., Waldock, 1963) at 162-3.

22 Ante, n. 1. "Article 1. For the purpose of these articles, the term "continental shelf" is used as referring (a) to the sea-bed and subsoll of the submarine areas adjacent to the coast but outside the area of the territorial sea, to a depth of 200 metres or, beyond that limit, to where the depth of the superjacent waters admits of the exploitation of the natural resources of the said areas: (b) to the sea-bed and subsoll ploitation of the natural resources of the said areas; (b) to
of similar submarine areas adjacent to the coasts of islands." 
earlier, just as some 19 th century principles are no longer acceptable today.

International law is a body of rules and practices which States accept as binding upon them. The absence in the system of both an international legislature and an international judicial hierarchy capable of authoring binding precedents means that the introduction of new concepts into the corpus of the law is accomplished with less chronological precision than is the case in a municipal system. In much the same ways as Canada, over a period of years matured from the status of a colony to one of sovereign independence, so do new concepts attract gradually the support of States and come to be recognized as law. In most instances it is difficult, if not impossible, to ascertain exactly when the law changed. It is possible only to state with confidence that in a certain year the law was such and such but that $x$ years later it was no longer that way.

(The "Memorandum of the Regime of the High Seas" prepared by the U.N. Secretariat and reprinted in 1950 Yearbook of the International Law Commission, Vol. II, p. 104, quoted with approval, an 1871 judgment of the Supreme Court of the United States ${ }^{23}$ as illustrative of this principle: "Many of the usages which prevail, and which have the force of law, doubtless originated in the positive prescriptions of some single State, which were at first of limited effect, but which when generally accepted became of universal obligation.")

The legal concept of sovereign rights in the continental shelf is an excellent example of this process:

-prior to World War II, the concept as now known was unheard of;

- the entry into force in 1964 of The Convention on the Continental Shelf marked the maturation of this new international legal concept;

-the intervening period of 25 years represented the ingestive cycle of the international community, passing through the several stages of unilateral claims and spreading acceptance.

Francis Vallat (later Sir Francis), legal adviser to $H$. M. Foreign Office, had occasion in 1946 to comment on the then state of legal development of the continental shelf concept. Referring to the "Truman Proclamation" of September 28th, 1945, ${ }^{24}$ he wrote: ${ }^{25}$

. . . while the unilateral declaration of the United States cannot in itself create any new rights or any new rules of international law, it may be regarded as providing the seed from which such rights and rules may grow. It is submitted that general recognition and acceptance by states may perfect the rights claimed by the United States and establish new rules of international law based on the doctrine of the continental shelf.

Prior to World War II, the seabed beneath the high seas was regarded either as having the same legal quality as the superjacent waters-res communis, ${ }^{25 a}$ or as being terra nullius. ${ }^{25 b}$ The only exceptions to these categorizations took the form of tunnelling from the coast, or certain historic claims to sedentary fisheries. Tunnels and oyster beds were simply exceptions to the general rule, or at most examples of effective

23 The Scotia, 14 Wall. 170; 21 L. Ed. 822.

24 Proclamation No. 2667, "Policy of the United States With Respect to the Natural Resources of the Subsoil and Sea Bed of the Continental Shelf", Sept. 28, 1945, 10 Fed. Res. 12303; XIII Dept. of State Bulletin, No. 327, at 485 .

25 "The Continental Shelf". XXIII B.Y.I.L. 333, at 337.

$25 a$ See Gidel, Vol. I, 498-501; Colombos, $3 d$ ed., at 56 .

$20 \mathrm{~b}$ See Fauchillp, 1925 vol. 1, part 2, 19; Hurst in 1923-24 B.Y.I.L., at 34. 
occupation of the ocean floor. They were by no means evidence of any acceptance in international law of a concept recognizing that to coastal States there appertained ipso jure the seabed. Sir Humphrey Waldock, Chichele Professor of International Law at Oxford, wrote in 1950: ${ }^{28}$

The important point which emerges from the writings of the jurists is that, despite variation in doctrine, they were at one in not recognizing any possibility of a legal title to the seabed or subsoil under the high seas being vested in a coastal State apart from effective occupation. The same is true of the small amount of state practice which existed in regard to submarine rights. There were a number of specific claims to exclusive rights to particular resources of the seabed in limited areas which were based on long enjoyment or at least on actual exploitation. The best known were various pearl, oyster and sponge fisheries. But these exclusive rights to resources in the seabed, when recognized as valid in law, were held to belong to the claimant States by reason of their actual enjoyment (generally from time immemorial) in particular areas and under a particular claim to exclusive jurisdiction. Similarly, in a few cases mineshafts sank ashore appear to have been driven outwards through the subsoil to points beyond the limit of territorial waters. These shafts were commonly said to constitute an effective occupation of the particular areas mined but no more. It is true that such claims to resources of the seabed or subsoil were made only by coastal States but they were justified as acts of occupation, not as the natural rights of coastal States. General or natural rights of adjacent extraterritorial resources were neither recognized nor claimed.

The practice of States bears out Waldock's views. A Foreign Office statement in the House of Commons in 1933, relating to the Ceylonese pearl fisheries, read as follows: ${ }^{27}$

Pearl fisheries stand on a different footing to the ordinary kind of fishing in the waters of the sea, because the banks where the pearl oysters lie must be treated as part of the bed of the sea. For many centuries the pearl banks off the coast of Ceylon have been claimed as subject to the sovereignty of the rulers of the neighbouring territory and subject therefore also to their control. Some of these banks are more than three miles from the shore, but where they are situated under the high seas, the claim to sovereignty and control is limited in extent to the area of the banks, and does not affect the rights of navigation or of ordinary fishing in the waters over the banks.

In 1918 an enquiry was directed to the U.S. State Department concerning oil deposits 40 miles off-shore in the Gulf of Mexico. The reply stated in part: ${ }^{28}$

... The United States has no jurisdiction over the ocean bottom of the Gulf of Mexico beyond the territorial waters adjacent to the coast .... it does not appear possible for the United States to grant to you the leasehold or other property rights in the ocean bottom which you desire.

The first attempt in the United States to assert a claim to the seabed did not mature. It took the form of Bill S.3744 (Senator Copeland) entitled "A Bill to Assert the Jurisdiction of the United States over Certain Portions of the Bering Sea and the Submerged Land Thereunder". The bill was passed by the Senate on May 5, 1938, but was never enacted.

The first actual claim by any State to the submarine resources took the form of an agreement between Great Britain and Venezuela entitled, "Treaty Relating to the Submarine Areas of the Gulf of Paria" dated February 26, 1942.29 Following this agreement, Britain issued the "United Kingdom (Trinidad and Tobago) Submarine Areas of the Gulf

26 "The Legal Basis of Claims to the Continental Shelf", (1950) XXXVI Transactions of the Grotius Societs 115, at 118 .

27 May 30, 1933; Hansard, Vol. 163, cols. 1417-8.

28 Hackworth, Digest of International Law, Vol. 2, at 680.

29 Britisil T.S. No. 10, 1942. 
of Paria (Annexation) Order-in-Council", dated August 6, 1942. ${ }^{30}$ The preamble to this Order-in-Council read in part as follows:

... and whereas the Government of the Republic of Venezuela have annexed to Venezuela certain parts of the submarine areas of the Gulf of Paria: and whereas it is expedient that the rest of the submarine area of the Gulf of Paria should be annexed to and form part of His Majesty's dominions and should be attached to the Colony of Trinidad and Tobago for administrative purposes ...

Of the above, one commentator has written: ${ }^{31}$

Previously, the only assertion of exclusive right generally recognized beyond the territorial sea and not arrived at by tunnel from shore had been to sedentary fisheries, and then only in certain limited cases based either on an historic claim or on effective occupation, or both.

... The treaty was the first legal act whereby rights of a territorial nature were claimed over zones beneath the high seas as an exception to the general regime of freedom prevailing therein.

And finally Sir Hirsch Lauterpacht, then at Cambridge but later a Judge of the International Court of Justice, wrote in 1950: ${ }^{32}$

While the various instances, prior to that date [August 6, 1942] of attempts at exploitation of the subsoil of the sea outside territorial waters and of references in official documents to the continental shelf or submarine areas generally are of some historical interest, the Paria Annexation Order may be regarded as the starting-point of the development.

The single greatest impetus to the shelf concept was of course the action taken by the United States in 1945 in the form of what has come to be referred to as the Truman Proclamation. ${ }^{33}$ This was followed by a rash of activity on the part of other States. ${ }^{34}$ The Truman Proclamation was not in any sense retrospective. It purported to extend national jurisdiction by a constitutive act. The interest stimulated by the United States action led to the inclusion by the International Law Commission in its draft Convention on the Law of the Sea of a number of articles on the continental shelf..$^{35}$ These articles were in turn considered by the Fourth Committee at the 1958 Geneva Conference on the Law of the Sea. ${ }^{36}$ The conference adopted the Convention, which came into force on June 10, 1964 following the deposit of the 22nd instrument of ratification. As of December 31, 1966, 37 States had ratified, including all the major maritime powers. Canada has not ratified the Convention; Canada has indicated, however, that it "is generally considered that the Convention formulates and develops rules which are applicable in international law generally." $3 i$

1958 , or perhaps 1964 , is a date of considerable significance. It marks the maturation of the concept of the continental shelf and its full acceptance by the international community. Public statements by some British Columbia spokesmen to the effect that the shelf "always has" been British Columbia's are inconsistent with this fact. As well, statements, articles and comments with respect to the shelf and written prior

i11 1942 Statutory Rules and Orders. Vol. 1, at 919.

31 Edwin J. Cosford. "The Continental Shelf," (1958) 4 McGill Law J. 245, at 258.

3. "Sovereignty Over Submarine Areas", XXVII B.Y.I.L. 376. at 379.

33 Ante, n. 24 . Shelf: Legislation and Proclamations," (1954) 3 Int'l. and Comp. L.Q. 535, at 553-5.

35 1956 Yearbook of the Int'!. Law Commission, Vol II, c. II, Arts 67-73.

30 Report of the Fourth Committee; U.N. Doc. A/CONF. 13/L. 12. The reader is referred to two articles describing the work of the Fourth Committee written by members of the United Kingdom and United States delegations respectively: J. A. C. Gutteridge, "The 1958 Geneva Convention on the Continental Shelf". XXXV B.Y.I.L. 102; Marjorie M. W. Whiteman. "Conference on the Law of the Sea: Convention on the Continental Shelf," (1958) 52 A.J.I.L. 629.

37 Statement of Canadian Under-Secretary of State for External Affairs, quoted at (1965) III C.Y.I.L. 325. 
to 1958 remain authoritative only to the extent that they are not inconsistent with the terms of the Convention. This because the Convention is an example of the work contemplated in the Statute of the International Law Commission: "the preparation of draft conventions on subjects which have not yet been regulated by international law or in regard to which the law has not as yet sufficiently developed in the practice of States."

Two attempts to cast backwards the notion of the continental shelf doctrine have been dealt with by international arbitral tribunals, both prior to the Convention. In the first case, Petroleum Development (Qatar) Ltd. v. Ruler of Qatar, ${ }^{35}$ the arbitrator, Lord Radcliffe, was asked to consider the effect upon an existing concession agreement of the intervening concept of the continental shelf. Lord Radcliffe simply recorded his conclusions and did not examine the principles involved. In the second case, Matter of an Arbitration between the Petroleum Development (Trucial Coast) Limited and His Excellency Shiekh Shakbut bin Sultan bin Za'id, Ruler of Abu Dhabi and its Dependencies, ${ }^{30}$ the arbitrator, Lord Asquith, did conduct such an examination. For that reason, and because of the eminence of the Counsel on either side-Sir Hirsch Lauterpacht, among others, for the oil company, and Sir Humphrey Waldock, among others, for the Sheikh of Abu Dhabi, the case is an important one.

The company had been granted, in 1939, the exclusive right for 75 years to drill for and extract oil in "the whole of the lands which belong to the rule of the Ruler of Abu Dhabi and its dependencies and all the islands and sea waters which belong to that area." A dispute arose as to whether the concession extended to the submarine areas outside the territorial seas.

The Arbitrator, Lord Asquith, posed a question similar to that in issue in the Canadian Reference: ". . . is the position . . . that the rights in the subsoil of the Shelf adhere (and must be taken always to have adhered) ipso jure-occupation or no occupation-to the contiguous coastal Power?"\$0

In the course of his award, Lord Asquith stated the following:

... I should certainly in $\mathbf{1 9 3 9}$ have read the expression the sea waters which belong to that area' not only as including, but as limited to, the territorial belt and its subsoil. At that time neither contracting party had ever heard of the doctrine of the Continental Shelf, which as a legal doctrine did not then exist. No thought of it entered their heads. None such entered that of the most sophisticated jurisconsult, let alone the 'understanding' perhaps strong, but 'simple and unschooled' of the Trucial Sheikhs. ${ }^{+1}$

Later:

Directed, as I apprehend I am, to apply a simple and broad jurisprudence to the construction of this contract, it seems to me that it would be a most artificial refinement to read back into the contract the implications of a doctrine not mooted till seven years later, and, if the view which I am about to express is sound, not even today [i.e. in 1952] admitted to the canons of international law.":

In summation, Lord Asquith observed that the Company's "primary contention is (1) that the doctrine of the Shelf is settled law, (2) that

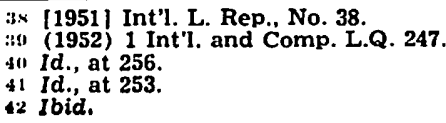


it always was so, and therefore that it was so in 1939; ergo, the meaning which some of the expressions in the contract would or might otherwise have borne is enlarged by the inclusion therein of the Shelf . . " $\mathrm{He}$ concluded: "The argument falls to the ground if I am right in rejecting the premise on which it rests, namely, that the doctrine of the Shelf has become and, indeed, was already in 1939, part of the corpus of international law."44

If Lord Asquith was correct in his conclusion that the shelf concept had not, in 1939, been accepted as part of the corpus of international law, a fortiori it was not in 1871, the date of entry of British Columbia into Confederation. Indeed it may be suggested that British Columbia's assertion that the shelf passed from the British Crown some time prior to 1871 is not in keeping with subsequent British practice. If Britain was equally as confident as British Columbia that the continental shelf had been vested in its colonies from the commencement of colonization, it surely would not have felt it necessary to assert claims to the shelf in 1948 on behalf of Jamaicats and the Bahamas, ${ }^{41}$ in 1950 on behalf of British Honduras ${ }^{47}$ and the Falkland Islands, ${ }^{48}$ and in 1958 on behalf of North Borneo, ${ }^{49}$ under the provisions of the Colonial Boundaries Act. ${ }^{50}$

Nor would it have enacted its 1964 Continental Shelf Act ${ }^{50 a}$ in the terms employed. Speaking of that statute, Professor D. W. Bowett of Cambridge University wrote recently: ${ }^{301}$

The Act makes clear that full sovereignty is not claimed over the shelf, and hence the necessity arises for specifically extending to the shelf and to installations and operations on the shelf the relevant parts of English law: there would have been no such necessity if the shelf were regarded as U.K. territory to which that law applied automatically. [emphasis added]

\section{IV}

Question 1 of the Reference is directed to the seabed of the territorial waters off the British Columbia coast. It asks, in effect, if these are part of British Columbia, or if they are subject to British Columbia's legislative jurisdiction. The province contends that this seabed belonged to the colony of British Columbia, and therefore came into Confederation in 1871 as part of the new province.

A number of 19th and early 20th century English and Scottish cases dealt with problems off the coasts: fishing by net and cable attached to the shore, ${ }^{51}$ digging for coal on shore below the high-water line, ${ }^{52}$ anchorage causing injury to oyster beds below, ${ }^{33}$ fowling on the foreshore, ${ }^{54}$ etc. None of these, however, appears sufficient in itself to

43 Id., at 258.

44 Id., at 259.

45 The Jamaica (Alteration of Boundaries) Order-in-Council 1948, No. 2575.

46 The Bahamas (Alteration of Boundaries) Order-in-Council 1948. No. 2574.

47 The British Honduras (Alteration of Boundaries) Order-in-Council 1950. No. 1649.

48 The Falkland Islands (Continental Shelf) Order-in-Council 1950, No. 2100.

49 The North Borneo (Definition of Boundaries) Order-in-Council 1958. No. 1517.

5058 \& 59 Vict., c. 34 .

soa U.K. Statutes, 1964 , c. 29.

50b D. W. Bowett, "The Law of the Sea", (Manchester, Manchester University Press, (1967) at 41 .

51 Gammell v. Woods and Forests Commissioners and Lord Advocate of Scotland, (1859) 31 Sc. Jur. 431

32 Att. Gen. v. Chambers, (1854) 43 E.R. 486.

63 Gann v. Whitstable Free Fishers, (1865) 11 E.R. 1305.

64 Lord Fitzhardinge v. Purcell, [1908] 2 Ch. 139. 
resolve unequivocally the question whether, in 1871, the British Crown considered the territorial sea and seabed to be part of the realm. One case does deal with this point, a highly uncertain judgment of the Court of Crown Cases Reserved, Regina v. Keyn..5 This special court had been asked to deal with a primarily jurisdictional question but the 13 judges (a fourteenth died before judgment was delivered) did not so confine themselves. This, plus the fact that the Court split 7-6, has long made the case a contentious one. The question before the Court arose out of a collision between a British vessel and a German ship, The Franconia, as a result of which a British subject lost his life. Did an English court-either the Admiral's court or the County courtpossess the jurisdiction to try the German officers of The Franconia for an offence committed in British territorial waters? The majority decided not. Several of the minority based their decision on an assumption that English legislation dealing with such matters as shipping regulations was evidence that the realm, and therefore the county, extended to the limits of the territorial sea.

The Australian scholar D. P. O'Connell examined the several judgments exhaustively in 1958 and came to this conclusion:

R. v. Keyn ... clearly decided, though by a narrow majority, that the territory of England ends at the low-water mark and the jurtsdiction of the Admiral which begins at that point did not, historically, embrace foreign nationals. To avoid the embarrassment of not being able to exercise policy control over foreigners in British territorial waters, Parliament intervened and in 1878 enacted the Territorial Waters Jurisdiction Act. (41 \& 42 Vict. c. 73) ... The 1878 Act merely recited that jurisdiction had always existed over territorial waters, which were defined as any part of the open sea within a marine league of the shore, and then proceeded to declare any offence in territorial waters to be within the jurisdiction of the Admiral. It was expressed to apply to all the Queen's dominions. There is no justification for the conclusion drawn in Halsbury (2nd Ed, Vol. 33, p. 520) that the soil of the sea between low-water mark and so far out to sea as is deemed by international law to be within the territorial sovereignty of the Crown, is claimed as the property of the Crown although outside the realm'. Cockburn, C. J., with whom the other majority Judges agreed, expressly stated that 'realm' and 'territory' are synonymous, and the suggested distinction between the two on which the Halsbury discussion is based is inherited from Hale and Bacon.

It is interesting to note that the 3rd Edition of Halsbury, although containing in the text the same words criticized by O'Connell above (and which is unquestionably the present law of England), now also recites in a footnote the judgment of Cockburn, C. J. to the effect that "the soil of the sea outside the body of a county and within the threemile limit was not prima facie vested in the Crown, as was the case of the bed and foreshores within the county, and has never been so vested except in the case of the bed of the sea off the coast of Cornwall by the Cornwall Submarine Mines Act." The footnote continues to say that "on the other hand, there are dicta of judges to the contrary" in other cases. ${ }^{57}$

Two English decisions followed shortly the Keyn case, and give some assistance in interpreting it. The first, Harris v. Owners of Franconia ${ }^{58}$ arose out of the same incident. In his judgment, Coleridge, C. J. (one of the minority in Reg. v. Keyn) stated:" "The majority of the

55 (1876) 2 Ex. 631.

56 "Problems of Australian Coastal Jurisdiction", XXXIV B.Y.I.L. 199, at 209-11.

s7 39 Halsbury's Laws 556, note (d) (3d ed. Simonds 1955).

$68 \llbracket 1877\rceil 2$ C.P.D. 173

so Id, at 177 . 
judges in $R$. v. Keyn were of opinion that the territory stopped at lowwater mark." In Blackpool Pier Co. v. Fylde Union, ${ }^{60}$ Coleridge, C. J. was joined by Grove, J., another of the minority in Reg. v. Keyn, in deciding whether a pier extending seaward 500 feet beyond low-water mark was properly assessable for local taxes. It was held that the pier was outside the realm of England and therefore not subject to the jurisdiction of the local taxing authorities. O'Connell in his article cites two opinions of Law Officers of the Crown which appear to support the same interpretation of Reg. v. Keyn. The second of these, dated March 16, 1877, stated: " "That the case of the Franconia seems to us to place limits upon the exercise of any jurisdiction on board foreign ships below low-water mark, and to show a distinction between land and the sea below low-water mark, though within the three mile zone."

Even had the realm, in 1871 , extended to the limit of the territorial sea, it does not necessarily follow that the territorial seas and seabed were vested in any colony, be it British Columbia or the Dominion of Canada. There is simply no evidence that either British Columbia or the Dominion at that early date were recipients from the British Crown of this marginal belt. ${ }^{62}$ Unquestionably, Canada did gain sovereignty over this belt but only at some later, ill-defined date as it approached full autonomy. ${ }^{6 s}$ If this be so, then British Columbia did not ipso jure acquire the territorial waters and the seabed beneath. This territory became part of the nation-State, to be dealt with pursuant to the constitution.

\section{V}

Any activities in the waters off Canada's coasts (be they in the territorial belt or seaward therefrom) are capable of giving rise to international consequences. Such consequences inevitably and without exception result in international responsibility for Canada. In these circumstances, the constitutional question designed to determine which of the parties, as of the date of the Reference, is entitled to positive answers from the Supreme Court cannot be answered in a judicial vacuum. This constitutional question, in the final analysis, has little to do with international law; it does, however, have much to do with international relations.

International law recognizes (as persons or entities) only members of the international community. At the present time these include the 140 or so independent States and those few international organizations which have been accorded international personality. Provinces of Canada are not international personalities. This means that should the provinces be accorded the right to engage in international activities, the

60 [1877] 36 L.T. 251.

61 C.O. Law Officers' Opinions, vol. 11i, No. 129.

62 This is in contrast to the quitclaim of all rights of the British Crown in favour of the 13 American colonies in the Treaty of Paris, 1783.

63 Perhaps by virtue of an Order-in-Councli dated July 31, 1880 which read in part as follows: "From and after the first day of September, 1880, all British Territories and Possessions in North America, not already included within the Dominion of Canada, and all Islands adjacent to any such Territories or Possessions, shall (with the exand all Islands adjacent to any such Territories or Possessions, shall (with the exnexed to and form part of the said Dominion of Canada;" Canada Gazette, 9 October. 1880. The present extent of Canadian Territorial Waters is determinable by The Territorial Sea and Fishing Zones Act, 1964 S.C., c. 22. For a discussion of these waters, see Jacques-Yvan Morin, "Les eaux territoriales du Canada au regard du Droit international," (1963) I C.Y.I.L. 82. 
international person responsible for those acts would be Canada. The present dispute is not similar to that which gave rise to the Labour Conventions Case, ${ }^{64}$ when international initiative by Canada was frustrated by a province. The award of the seabed to British Columbia would mean the reverse: that British Columbia on its own initiative, not Canada, could decide when and where Canadian responsibility would commence. The issue is unquestionably one of distribution of sovereign rights but the consequences are international; Canada is required to answer in the international forum for acts of its constituent parts, these latter not having any international personality.

(Courts have in the past paid heed to the international ramifications of domestic Canadian disputes when giving judgment. The Judicial Committee of the Privy Council did so, in both the B.C. Fisheries Case and the Quebec Fisheries Case, discussed earlier. ${ }^{65}$ )

It was in anticipation of international activities of one sort or another that the United States was prompted to claim sovereignty over the continental shelf, and then later to contest the attempts of several states to claim part of those sovereign rights. In June 1945, a State Department spokesman in Washington expressed the American policy in these words in a discussion with the British Minister: ${ }^{86}$

Our primary concern was to assert the necessary control over such operations off the coasts of the United States to guard against the depletion of our mineral resources and to regulate, from point of view of security, the activities of foreigners in proximity to our coast.

In a subsequent memorandum from the Office of the Legal Adviser to the Secretary of State: ${ }^{67}$

In the exercise of its rights of self-protection and as a matter of national defence, the United States could not view without serious concern any attempt by a foreign power or the nationals thereof to exploit the resources of the continental shelf off the coast of the United States, at points sufficiently near the coast to impair or endanger its security, unless such activities were undertaken with its approval.

The United States later became engaged in contests with several of the states over the ownership of the minerals in the seabed beneath the territorial sea. (These cases have come to be described, erroneously, as the "tidelands" controversy.) Never, however, did any American state lay claim, as British Columbia does, to the resources in the subsoil seaward of the territorial zone. Unquestionably, the American tidelands cases may be distinguished from the Canadian Reference because of important historical and constitutional differences. Nevertheless, the words of the Supreme Court of the United States, which reflect the concern of the United States should a state and not the federal government be accorded the right to engage in activities off the coast resulting in international responsibility for the United States, are valuable as illustrative of the international consequences which should, it is submitted, be considered by the Supreme Court of Canada in the present Reference.

The first of the three principal contests over the offshore seabed argued before the Supreme Court of the United States was that of United States

64 Att. Gen. Canada v. Att. Gen. Ontario, [1937] A.C. 326.

65 See ante, n. 11 and 13.

60 Whiteman, Digest of Internaíional Law, Vol. 4, at 754

67 Id., at 755 . 
v. California. ${ }^{68}$ In the course of its decision, delivered by Justice Black, the Court stated: ${ }^{00}$

The crucial question on the merits is not merely who owns the bare legal title to the lands under the marginal sea. The United States here asserts rights in two capacities transcending those of a mere property owner. In one capacity it asserts the right and responsibility to exercise whatever power and dominion are necessary to protect this country against dangers to the security and tranquility of its people incident to the fact that the United States is located immediately adjacent to the ocean. The Government also appears in its capacity as a member of the family of nations. In that capacity it is responsible for conducting United States relations with other nations. It asserts that proper exercise of these constitutional responsibilities requires that it have power, unencumbered by state commitments, always to determine what agreements will be made concerning the control and use of the marginal sea and the land under it.

British Columbia will unquestionably argue that the various powers given to Canada under Section 91 of the British North America Act, 1867-defence, ${ }^{70}$ navigation and shipping, ${ }^{71}$ fisheries ${ }^{72}$ - ${ }^{2}$ adequately to discharge its international responsibilities even though the property in the seabed is vested in the coastal provinces. This argument will be designed to rebut the reasoning of the California decision for it, in effect, urges the separation of imperium and dominium. The Supreme Court of the United States was invited to perform the same surgery in United States v. Texas. ${ }^{73}$ The court replied: ${ }^{74}$

... And so although dominium and imperium are normally separable and separate [see the statement of Mr. Justice Field (then Chief Justice of the Supreme Court of California) in Moore v. Smaw, 17. Cal. 199 at pp. 218-219], this is an instance where property interests are so subordinated to the rights of sovereignty as to follow sovereignty.

It is said that there is no necessity for it-that the sovereignty of the sea can be complete and unimpaired no matter if Texas owns the oil underlying it. Yet, as pointed out in United States v. California, once low-water mark is passed the international domain is reached. Property rights must then be so subordinated to political rights as in substance to coalesce and unite in the national sovereign. Today the controversy is over oil. Tomorrow it may be over some other substance or mineral or perhaps the bed of the ocean itself. If the property, whatever it may be, lies seaward of low-water mark, its use, disposition, management, and control involve national interests and national responsibilitities. That is the source of national rights in it.

The United States Supreme Court employed similar language in United States v. Louisiana: ${ }^{75}$

Protection and control of the area [the three mile belt] are indeed functions of national external sovereignty. The marginal sea is a national, not a state concern. National interests, national responsibilities, national concerns are involved. The problems of commerce, national defence, relations with other powers, war and peace focus there. National rights must therefore be paramount in that area. ${ }^{76}$

The Continental Shelf Convention, ratified as it now is by 37 States (as of December 31, 1966) is generally declaratory of existing international law on this subject, and is so regarded by Canada. ${ }^{77}$ Should

\footnotetext{
68332 U.S. 19.

09 Id., at 29 .

70 S. 91 ( 7$)$.

71 S. 91 (10).

72 S. 91 (12)

73339 U.S. 707.

74 Id., at 719

75339 U.S. 699 , at 704 .

76 Subsequent to its judicial victories in these three cases, the federal government moved to make a political settlement with the coastal states. The Submerged Lands Act, ante, $n$. 10, was enacted by Congress on May 22, 1953. This Act transferred to the ante, $n$, 10 , was interest in all lands beneath navigable waters to a distance seaward of 3 geographic miles off the Atlantic and Pacific coasts, and to a distance seaward of 3 marine leagues into the Gulf of Mexico.

77 See ante, $\mathrm{n} .37$.
} 
Canada become involved in an international dispute with respect to the shelf, there is no doubt that a competent adjudicative or arbitral tribunal would look to the Convention as a means of determining the obligations owing by the coastal State to other members of the community. Canada, not one of its constituent provinces, is the international personality to which other States must look for compensation should the responsibilities of the coastal State not be discharged. These responsibilities, as set out in the Convention, are several:

1. An obligation not to interfere with the rights of other States in the waters above the shelf and in the superjacent air space.-Art. 3.

2. An obligation not to impede the laying or maintenance of submarine cables or pipe lines on the continental shelf.-Art. 4.

3. An obligation to avoid any unjustifiable interference with navigation, fishing or the conservation of the living resources of the sea.-Art. 5 (1).

4. An obligation not to interfere with fundamental oceanographic or other scientific research carried out with the intention of open publication.-Art. 5 (1).

5. An obligation to give due notice of the establishment of any safety zones around the installations or devices constructed on the continental shelf for the purpose of exploration or exploitation of its natural resources.-Art. 5(5).

6. An obligation to maintain permanent means for giving warning of the presence of any such installations or devices.-Art. 5(5).

7. An obligation to remove entirely any such installations which are abandoned or disused.-Art. 5(5).

8. An obligation not to establish installations or devices, or safety zones around them, where interference may be caused to the use of recognized sea lanes essential to international navigation.Art. 5(6).

9. An obligation to undertake, in the safety zones, all appropriate measures for the protection of the living resources of the sea from harmful agents.-Art. 5(7).

10. An obligation not normally to withhold consent for the carrying out of purely scientific research into the physical or biological characteristics of the continental shelf by a qualified institution intending to publish the results.-Art. 5(8).

It is difficult to envisage how a judgment in favour of British Columbia would work in practice. The coastal province would then have the opportunity, for its own extraction and exploitation purposes, to act or fail to act in ways that could result in international responsibility for Canada. It is far from clear that Canadian legislative authority would protect Canada against such provincial activities. Indeed, even should British Columbia observe carefully all international standards of conduct, and take care not to breach any of the requirements contained in the Continental Shelf Convention, it would nevertheless be able to interfere seriously with the conduct of Canada's foreign relations. One need only consider, as an example, the reaction of the United States should 
the British Columbia government lease certain submarine minerals to a Soviet operator which latter then proceeded to erect in the Straits of Juan de Fuca (outside the shipping channels) an offshore structure bristling with electronic detection apparatus. This would make a mockery of Canada's responsibilities for defence.

One need not look to hypothetical examples, however. Oil has proved historically its capacity to incite the passions of men and nations. Its presence beneath many fathoms of water has not changed this feature. At the present time in the North Sea, there are disputes involving Denmark, the Netherlands and West Germany concerning the international demarcation of the shelf. Recently settled was a dispute between Britain and Norway. In the waters off Newfoundland, Canada is contesting a claim by France, based on the latter's sovereignty over the islands of St. Pierre and Miquelon, to a large section of the continental shelf. In this latter contest Canada's negotiating strength could be seriously jeopardized should France gain the impression that Canada did not retain sole jurisdictional sovereignty over the areas in question. Canada's coastlines are the longest in the world, and international complications may be anticipated with the United States in several places, as well as with Denmark near Greenland. Should the depths of exploitation prove even greater, claimants from many States will meet in mid-ocean.

There is thus already an actual international conflict. It is complicated by the unilateral act of Newfoundland claiming to itself sovereign rights in the continental shelf in an area claimed by France. A second actual conflict is quite possible: British Columbia has claimed jurisdiction to parts of the shelf which fall within the jurisdiction of the United States under the median line principle enunciated in Article 6 of the Convention. The comments attributed to Victoria sources (and discussed above) to the effect that British Columbia might "colonize" the shelf reveal the intolerable sort of situation that could ensue. ${ }^{78}$

Canada's sovereign prerogative for the conduct of foreign policy would be diminished considerably should the Supreme Court answer in favour of British Columbia the several questions in the Reference. A Pandora's box would be opened with the result that those provinces with seacoasts would be vested with a propensity for international activity bearing little semblance to "Matters of a merely local or private Nature in the Province."79

It would be ironical if, in this centennial year, the Supreme Court of Canada felt itself obliged to move far beyond Lord Atkin's ill-designed "watertight compartments" by creating, in effect for certain purposes, a whole flotilla of vessels capable of succouring themselves in the lee of the original ship of state, and at its expense.

78 Presumably this means that British Columbia would Ignore the provisions of the Convention and revert to the old surface techniques of discovery, exploration and occupation.

io British North America Act, 1867, s. 92 (16). Indeed it could be argued that the effect of the decision of the Judicial Committee of the Privy Council in Nadan $v$. The Kitg, [1926] A.C. 482 (asserting the incompetence of provinces to legislate extraterritorially) would be destroyed. 